\title{
As cachoeiras como bolsões de histórias dos grupos indígenas das terras baixas sul-americanas
} Interpreting waterfalls as pockets of histories of Indigenous groups from the South-American Lowlands

Fernando Ozorio de Almeida*

Thiago Kater ${ }^{* *}$

\section{RESUMO}

$\mathrm{O}$ artigo discute o papel das cachoeiras como locais que por milhares de anos foram constantemente visitados e ocupados por coletivos indígenas das terras baixas sul-americanas. Nossos guias foram a análise da paisagem e da cultura material pertencentes a sítios arqueológicos que surgem no entorno desses lugares a partir do Holoceno Inicial. Como exemplo do potencial histórico das cachoeiras, apresentamos três sucintos estudos de caso: Teotônio (alto Madeira); Tucuruí (baixo Tocantins) e Xingó (baixo São Francisco). A principal conclusão é que esses marcos paisagísticos devem ser compreendidos como bolsões de histórias e devem receber atenção especial quanto à sua preservação. Palavras-chave: cachoeiras; lugares persistentes; cerâmica arqueológica.

\section{Abstract}

The main objective of this article is to discuss how waterfalls and rapids were constantly visited and occupied for thousands of years by indigenous collectives from the South-American lowlands. Landscape analysis and material culture from archaeological sites, that appear since the early Holocene on the surrounding areas of these places, were our guides. We present three case studies as examples of the historical potential of the waterfalls: Teotônio (Upper Madeira), Tucuruí (Lower Tocantins) and; Xingó (Lower São Francisco). Our main conclusion is that these landmarks should be understood as pockets of histories and should receive special attention as to their preservation.

Keywords: waterfalls (rapids); persistent places; archaeological ceramics.

\footnotetext{
* Laboratório de Paisagem e Sociedade, Departamento de Arqueologia, Programa de Pós-Graduação em Arqueologia, Universidade Federal de Sergipe (UFS). Coordenador Científico do Museu de Arqueologia de Xingó. Laranjeiras, SE, Brasil. fernandozorio@hotmail.com

** Mestrando em Arqueologia, Laboratório de Paisagem e Sociedade, Programa de Pós-Graduação em Arqueologia, Universidade Federal de Sergipe (UFS). Laranjeiras, SE, Brasil. thiagokater@hotmail.com
} 
"Então onde o passado existe, se de fato existe?"

"Nos documentos. Está registrado ... Na mente. $\mathrm{Na}$ memória humana."

(Orwell, 2009, p.291-292)

A sociedade distópica construída por George Orwell em 1984 vez ou outra volta à tona, reenquadrada por diferentes nuances, como um futuro possível para a humanidade. No diálogo da epígrafe, O’Brien, um membro do alto escalão do partido que controla a sociedade, inquire o protagonista Winston Smith sobre quais eram os impeditivos concretos para se modificar o passado.

A afirmativa final de O'Brien é direta: o partido controla os documentos e a memória, logo controla o passado. Historiadores e arqueólogos, especialistas por excelência em "estudar o que resta do passado" sabem que O'Brien tem, nesse ponto, razão. O passado não existe enquanto tal (Ginzburg, 2007, p.265, por exemplo). Trabalha-se por meio de vestígios, resquícios e evidências da existência de coisas que permanecem, que não apenas foram, mas ainda são.

Papéis queimados, fotografias adulteradas e notícias reescritas. Apesar da atualização programática dos documentos, há um elemento que tanto Winston quanto O'Brien e os desavisados membros do partido não perceberam: o espaço, a paisagem e os vestígios de materiais não perecíveis também são resquícios desse passado. Apesar de o cenário que compõe 1984 ser uma Londres remodelada e renomeada pelo partido, ainda é possível, com certo esforço, vislumbrar resquícios inteligíveis do passado. Winston, para quem a arquitetura não fornecia melhores mecanismos para se conhecer a história, já que nunca havia imaginado que velhos edifícios tivessem sido igrejas, surpreende-se com a réplica do sr. Charrington, o velho proprietário da loja de quinquilharias: “Ainda há uma porção delas por aí, só que hoje são usadas com outros fins” (Orwell, 2009, p.120).

É sobre essas paisagens esquecidas, ou invisíveis, que queremos tratar. Nas paisagens e no espaço se incrustam as ranhuras e as cicatrizes do tempo, e é possível encontrá-las, dotando cada uma de sua história. Uma história que não está inscrita nos textos, mas nas coisas. É por meio dessas paisagens e artefatos arqueológicos que propomos evidenciar os grupos indígenas enquanto agentes de sua história.

Neste artigo pretendemos abordar os sítios arqueológicos, antigas ocupações indígenas, que existiam no entorno de cachoeiras das terras baixas sul-americanas. Atualmente essas áreas são de grande interesse para a construção 
de usinas hidrelétricas, muitas vezes servindo como fonte de energia para populações localizadas a milhares de quilômetros dali. Até algumas centenas de anos atrás, entretanto, muitos desses locais atraíam pessoas vindas de lugares distantes para a realização de rituais (comércio, iniciação, enterrar os mortos etc.) e/ou para moradia. Serviam como áreas de concentração de pessoas e eram, portanto, áreas de sumidouros de eventos e processos históricos milenares.

A arqueologia brasileira, utilizando diferentes estratégias e temporalidades, pode colaborar na construção de uma história indígena anterior e posterior à conquista europeia (Heckenberger, 2001; Neves, 2012; Almeida, 2013a; Corrêa, 2013; Zuse, 2014). Se o tempo é plural e de diferentes durações (Braudel, 1990), é naquele profundo - o geográfico de longa duração - em que as mudanças são mais lentas e as permanências mais visíveis, que uma história indígena pela via arqueológica se torna mais palpável (Heckenberger, 2001; Neves, 2012; Corrêa, 2013).

Desse modo, o protagonismo histórico das sociedades indígenas também se perscruta nos espaços geográficos. É nesses lugares distintivos que a história se encena, rememora-se e se faz presente, ainda que, como as igrejas em 1984, tais locais sejam usados, hoje, para "outros fins". Como Winston, é preciso modificar o olhar.

As cachoeiras, dentre uma porção de lugares, são exemplos de que uma alteração na forma de olhar pode trazer à tona histórias aparentemente esquecidas. Em uma analogia historiográfica, elas fazem as vezes do mar Mediterrâneo de Braudel (1990).

\section{AS CACHOEIRAS COMO LUGARES SIGNIFICATIVOS E PERSISTENTES}

Conforme adverte O’Brien, o passado não nos é acessível enquanto tempo (Orwell, 2009, p.291), entretanto, pode ser como paisagem: um passado que encerra suas raízes no presente, por meio dos fragmentos materiais das realizações sociais pretéritas (Santos, 2004, p.14-15). Não sendo a oposição entre cultura e natureza, mas "a matéria trabalhada por excelência" (Santos, 2005, p.34), a paisagem é a confluência de ações e tempos passados que se entrelaçam em um presente (González Ruibal, 2006):

A paisagem existe através de suas formas, criadas em momentos históricos diferentes, porém coexistindo no momento atual. No espaço, as formas de que se compõe a paisagem preenchem, no momento atual, uma função atual, como resposta às necessidades atuais da sociedade. (Santos, 2002, p.104, grifo no original) 
As paisagens tornam-se lugares significativos, isto é, um espaço no qual as pessoas (inter)agem tanto com o meio ambiente quanto com o sobrenatural, sem que seja preciso modificá-lo, quando se reconhece a existência desse determinado local, individual e coletivamente, por meio das experiências e pelas memórias partilhadas pelo grupo, definindo assim sua significância (Zedeño; Bowser, 2009, p.5). A longa duração no uso desse espaço o transforma, ainda que sejam alterados seus significados, em um lugar persistente (Zedeño; Bowser, 2009, p.12).

Partimos do pressuposto de que é possível considerar as cachoeiras não só como elementos físicos e ambientais, mas como lugares significativos para os povos indígenas - constituídos por componentes ideológicos, históricos, econômicos e territoriais. Certamente a formação de ecótonos (Almeida, 2017), áreas abundantes em alimento, com fartura de peixes e outras importantes fontes proteicas, como animais aquáticos de maior porte, faz das cachoeiras áreas de interesse econômico. Marcos físicos e estratégicos tornam-se, para quem sobe ou desce um rio, pontos de parada, entrepostos para comércio e para troca de dádivas (Mauss, 2012), espaços de política, de disputa e de tomadas de decisão.

No entanto, não é somente por essa chave interpretativa que se dota de significância uma cachoeira; o caráter ideológico e o simbólico precisam ser levados em consideração. Diversos mitos indígenas, em diferentes áreas das terras baixas sul-americanas, compreendem as cachoeiras como locais sagrados, de nascimento do mundo. Sendo parte importante da cosmologia e dos mitos de origem, as cachoeiras desempenham papel central para se pensar o ordenamento do mundo, do território e da própria vida (Goldstein, 2009). Para povos do alto rio Negro, como os Tariano, Tukano, Desana, Pira-Tapuia, Wanano e Tuyuka, a cachoeira de Iauaretê, no alto rio Negro, no noroeste da Amazônia, tem significância ímpar na conformação de sua identidade e territorialidade, pois foi "um dos pontos de parada da cobra-canoa que trouxe ao Uaupés seus ancestrais” (Goldstein, 2009, p.334). Da mesma forma, muitos coletivos indígenas, como os Jívaro da Amazônia Oriental, utilizam áreas de cachoeiras para a realização de atividades de iniciação dos rapazes (Harner, 1972). Por fim, a arqueologia demonstra que, além de berço da humanidade e local de passagem entre os períodos da vida ou entre lugares de viver, as cachoeiras também serviam para os momentos de transição ao mundo dos mortos, já que é comum encontrar cemitérios nesses locais.

Vista como um lugar ancestral ou mítico, em virtude dessa dimensão simbólica uma cachoeira pode integrar o imaginário de uma população, 
mesmo que seja esporadicamente - ou mesmo nunca - visitada (Russell, 2012). Assim, os vestígios antigos que se acumulam sedimentados no entorno das cachoeiras, os quais permitem caracterizá-la como paisagem histórica e arqueológica, acabam por propiciar o substrato às narrativas históricas elaboradas por esses grupos (Sammark; Semple, 2010) e por nós mesmos.

Se nesses casos o componente ideológico não exclui o viés material, e vice-versa, eles se integram formando a base física, geográfica, histórica e mental de uma sociedade. Sujeitas a variações e fluidez, essas paisagens constituem-se no território enquanto espaços de identificação, o que implica construção, controle, engajamento e modificação (Saquet, 2009).

Dentro de fronteiras fluidas, como eram as indígenas, imersas em variadas territorialidades (Saquet, 2009), as cachoeiras podem ser vistas como áreas centrais, nas quais se sobrepõem distintos territórios; são os "nós" e entroncamentos nessas redes; marcadores geográficos e simbólicos; ponto de encontro para grupos (Saquet, 2009; Sammark; Semple, 2010) ou ainda espaços rituais e de peregrinação (Almeida, 2013a). Podendo conter simultaneamente essas diferentes funções, inclusive algumas divergentes (Santos, 2005, p.138-139), são formadas ao longo e pelo acúmulo dos resquícios das diferentes intervenções humanas durante a história.

Diante dessa caracterização generalista de cachoeiras, propomos abordar sucintamente três contextos geográficos distintos, a fim de verificar seu potencial histórico/arqueológico. As áreas de estudo são: (I) a cachoeira de Teotônio, no alto rio Madeira; (II) a de Tucuruí, no rio Tocantins e, por fim, (III) as corredeiras de Xingó, no rio São Francisco (Figura 1). Essas áreas foram escolhidas porque são foco de pesquisas dos autores durante os últimos anos. Para quase todas as demais cachoeiras brasileiras que foram transformadas em hidrelétricas existem estudos arqueológicos particulares - de licenciamento e/ ou acadêmicos (Miller et al., 1992, por exemplo) - que permitem visualizar diferentes contextos com a presença de bolsões de história.

Ao fornecer subsídios interpretativos para cada um desses "bolsões de história”, essas cachoeiras permitem a discussão das histórias de representantes de grandes agrupamentos linguísticos, como os Tupi-Guarani, Arawak, Pano e Macro-Jê. Portanto, um olhar direcionado, modificando a maneira de se encarar essas paisagens, torna os diversos povos indígenas - que ao longo do tempo as transformaram, por meio de diversos intentos - em protagonistas de sua história. 


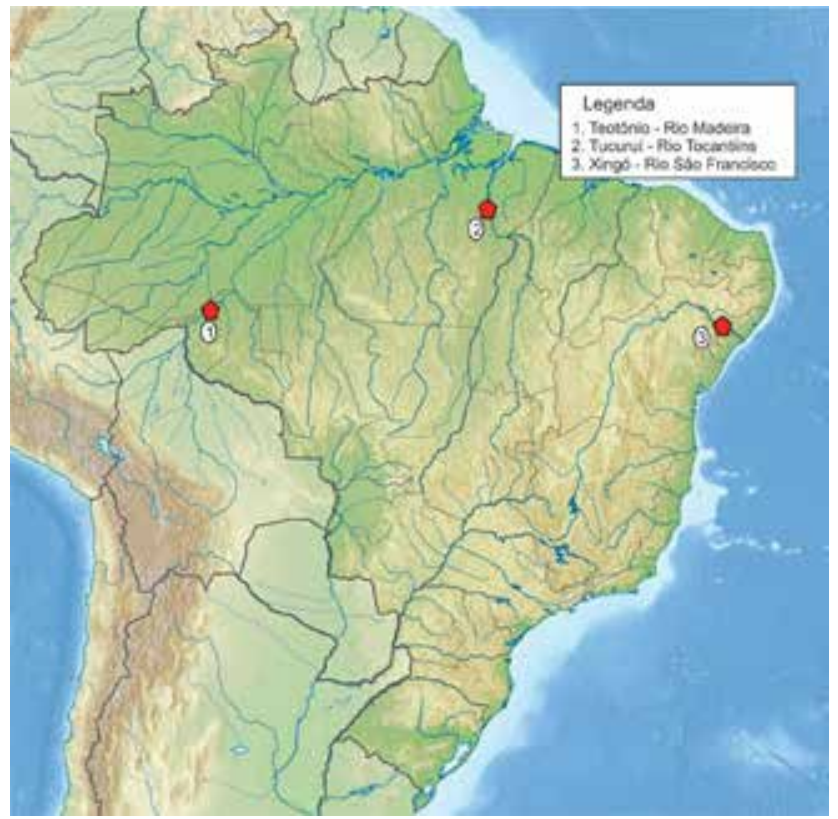

Figura 1 - Os três contextos trabalhados no presente artigo

\section{No MEIO DO CAMINHO HAVIA UMA CACHOEIRA: o sítio TeOTÔNIO E O ALTO RIO MADEIRA}

A bacia do rio Madeira, no sudoeste amazônico, estende-se por aproximadamente 1,4 milhão de $\mathrm{km}^{2}$, correspondendo a quase $20 \%$ de toda a bacia amazônica. Maior tributário do Amazonas, em carga líquida e sólida, forma-se pela junção dos complexos fluviais Beni/Madre de Dios e Guaporé/Mamoré, cursando $1.700 \mathrm{~km}$ em sentido sudoeste-nordeste (Tizuka, 2013). Elo entre a Amazônia, a região pantaneira e os Andes, a bacia do rio Madeira se apresenta como um espaço-chave para compreensão do passado indígena. $O$ clima equatorial com vegetação de floresta tropical é o predominante na região atravessada pelo rio, ocorrendo, no entanto, áreas de cerrado, a oeste do estado de Rondônia (Ab'Saber, 2004).

Ao registro arqueológico identificado no sudoeste amazônico associam-se datações que remontam a $12 \mathrm{mil}$ anos AP (Antes do Presente) e que, a partir de 9 mil anos AP, perpassam todo o Holoceno ${ }^{1}$ (Miller, 1992). Marcado tanto pela antiguidade quanto pela continuidade das ocupações humanas, o processo 
histórico ocorrido na bacia do rio Madeira se distingue de boa parte do restante da Amazônia (Neves, 2012). À longa duração de presença humana acrescentam-se outros componentes que podem fornecer importantes aportes interpretativos.

O sudoeste amazônico é o provável centro de domesticação da mandioca (Manihot esculenta) e da pupunha (Bactris gasipaes), plantas extremamente relevantes, não só na dieta alimentar, mas simbolicamente, para as populações indígenas (Clement, 1999, p.200). É também o centro de origem e dispersão dos povos do tronco linguístico Tupi (Urban, 1992; Rodrigues; Cabral, 2012). Além disso, identifica-se historicamente na região uma alta diversidade cultural e linguística, na qual interagiam grupos de matrizes linguísticas diversas, como povos falantes de língua Arawak, Pano, Txapakura e de línguas isoladas (Menéndez, 1981). Por fim, é onde também se encontram as mais profundas e mais antigas "terras pretas antropogênicas"2 da Amazônia, o que sugere que o processo de sedentarização na floresta tropical pode ter se iniciado nessa região (Neves, 2012).

No alto curso do rio Madeira, que é grosso modo sua área encachoeirada, junto à segunda cachoeira rio acima, localiza-se o sítio arqueológico Santa Paula, na margem esquerda, ao passo que na margem direita está o sítio Teotônio. A cachoeira homônima foi submersa no início de 2013, quando a UHE (Usina Hidrelétrica) Santo Antônio entrou em operação.

Até então, a cachoeira de Teotônio era um marco distintivo no local. No período colonial, quando de viagens por esse trecho, há menção ao lugar, destacando sua monumentalidade, ora enfatizando-se a violência de suas quedas d'água, ora sua piscosidade (Fonseca, 1881; Abreu, 1989, p.121; Goulding; Smith; Mahar, 1996, p.109). Apesar de ser a segunda cachoeira para as viagens que subiam pelo rio, era a primeira não navegável, sendo transposta somente por via terrestre.

A dificuldade logística que a cachoeira impunha aos colonizadores foi uma das motivações para a criação, por Teotônio de Gusmão, de uma vila no local, em meados do século XVIII, chamada de Nossa Senhora da Boa Viagem do Salto Grande (Fonseca, 1881, p.79), mas que, na verdade, era um aldeamento de índios Pâma (Menéndez, 1981, p.305). A vila logo foi abandonada pelos colonizadores, mas a cachoeira passou a ser conhecida com o nome de seu fundador.

De certo modo, o que explica parcialmente o declínio da navegação do rio Madeira são as hostilidades contínuas de alguns coletivos indígenas. O cronista da viagem de Francisco Palheta, encarregado pelo governo provincial de 
descobrir as cabeceiras desse rio em 1722 (Abreu, 1989), afirma que conforme iam se distanciando das primeiras cachoeiras, nas quais os indígenas guias da expedição ainda conseguiam dialogar na língua de seus cunhamenas (parentes), a língua ficava ininteligível (Abreu, 1989). Assim, as relações interétnicas prévias à colonização, sugeridas pela grande diversidade linguística local, são um fator importante ao se considerar associações ou resistências dos grupos indígenas aos colonos.

Os Mura, por exemplo, eram descritos como um povo nômade, que vivia em suas embarcações subindo e descendo o rio Madeira. Hostis às populações coloniais e a alguns outros grupos étnicos, eram temidos por atacarem tanto frotas quanto estabelecimentos e vilas (Fonseca, 1881; Menéndez, 1981, p.306307). Enquanto a presença Mura já havia sido notada pelos cronistas no século XVIII, os Munduruku tornam-se protagonistas de relatos históricos a partir do século XIX, quando ocuparam de forma incisiva boa parte do baixo rio Madeira e de sua foz, o que sugere migrações e deslocamentos desses grupos (Menéndez, 1981). É somente com o ciclo da borracha, para o qual muitos indígenas Pano foram cativos, no fim do século XIX, que a cachoeira do Teotônio voltou a ter uma vila.

A breve história colonial do local, no entanto, contrasta com as evidências arqueológicas a respeito das populações indígenas na cachoeira. Com ocupações contínuas que remontam a pelo menos 6.500 anos AP (Mongeló, 2015), os dados obtidos pelo Projeto Alto Madeira (PALMA), que desde 2011 realiza intervenções arqueológicas no sítio Teotônio, sugerem que a cachoeira seja um microcosmo do processo histórico ocorrido nessa bacia, quiçá nas terras baixas sul-americanas.

Povos produtores de cerâmica deixaram evidências de suas ocupações por meio de fragmentos de vasos e vasilhas. As semelhanças ou diferenças nas formas de se manufaturar os potes cerâmicos podem indicar afinidades culturais. Ao utilizar uma cronologia que atinge os últimos 3 mil anos AP (Miller, 1992; Almeida, 2013a), propomos uma visão sincrônica e diacrônica desses materiais que nos servem de vestígios para elaborar uma narrativa a respeito do processo histórico regional.

O grande diferencial dos sítios próximos à cachoeira é que o registro encontrado parece agregar atributos cerâmicos que se espalham isoladamente em boa parte dos sítios existentes tanto nos afluentes quanto na calha do Madeira. O Quadro 1 apresenta uma relação generalista a respeito dos diferentes conjuntos cerâmicos identificados na área da cachoeira do Teotônio. Por não ser nosso intuito neste artigo, a discussão arqueológica a respeito da 
tecnologia de fabricação cerâmica não será esmiuçada. Outra advertência é que a associação entre os conjuntos cerâmicos e as famílias linguísticas deve ser pensada como válida para processos multivariados e em grandes escalas espaciais - e não como uma relação obrigatória (Almeida; Neves, 2015).

\section{Quadro 1 - Principais agrupamentos cerâmicos da região do alto Madeira}

\begin{tabular}{|c|c|c|c|c|}
\hline $\begin{array}{c}\text { Tradição / } \\
\text { Fase }\end{array}$ & Descrição & Localização & Cronologia & $\begin{array}{c}\text { Filiação } \\
\text { Linguística }\end{array}$ \\
\hline Pocó & $\begin{array}{l}\text { Manufatura } \\
\text { roletada, com } \\
\text { antiplástico mineral, } \\
\text { caraipé ou carvão. } \\
\text { Superfícies polidas e } \\
\text { paredes com } \\
\text { espessura fina } \\
\text { (inferior a } 1 \mathrm{~cm} \text { ). } \\
\text { Diferencia-se pela } \\
\text { grande presença de } \\
\text { decoração incisa } \\
\text { e de pinturas de } \\
\text { diferentes } \\
\text { tonalidades. Maioria } \\
\text { dos vasos com } \\
\text { pequenas } \\
\text { capacidades } \\
\text { volumétricas } \\
\text { (<15L). As formas } \\
\text { possuem contorno } \\
\text { simples, geralmente } \\
\text { com formas abertas } \\
\text { e irregulares. Boa } \\
\text { parte dos vasos } \\
\text { parece ser para } \\
\text { consumo individual } \\
\text { e/ou coletivo de } \\
\text { líquidos. }\end{array}$ & $\begin{array}{l}\text { Calha principal } \\
\text { do rio Madeira. } \\
\text { Presença } \\
\text { pontual em boa } \\
\text { parte da bacia } \\
\text { amazônica. }\end{array}$ & $\begin{array}{l}2900-1000 \\
\text { anos AP }\end{array}$ & Arawak \\
\hline
\end{tabular}




\begin{tabular}{|c|c|c|c|c|}
\hline Barrancoide & $\begin{array}{l}\text { Manufatura } \\
\text { predominantemente } \\
\text { roletada, com alguns } \\
\text { escassos fragmentos } \\
\text { modelados. } \\
\text { Superfícies alisadas } \\
\text { medianamente e } \\
\text { paredes entre } 0,8 \text { e } \\
1,0 \text { cm de espessura. } \\
\text { Presença de incisões } \\
\text { e apliques zoomorfos. } \\
\text { Pinturas são quase } \\
\text { ausentes. Maioria dos } \\
\text { vasos é de contorno } \\
\text { regular e formas } \\
\text { abertas e fechadas, } \\
\text { com ampla variação } \\
\text { na capacidade } \\
\text { volumétrica. }\end{array}$ & $\begin{array}{l}\text { Calha principal } \\
\text { do rio Madeira. } \\
\text { Presente em } \\
\text { toda a bacia } \\
\text { amazônica. }\end{array}$ & & Arawak \\
\hline Jamari & $\begin{array}{l}\text { Manufatura roletada. } \\
\text { Antiplástico principal } \\
\text { é o caraipé. } \\
\text { Alisamento da } \\
\text { superfície de } \\
\text { mediano a fino. } \\
\text { Paredes espessas } \\
\text { (>0,8 cm) com } \\
\text { grande quantidade de } \\
\text { fuligem. Decorações } \\
\text { são escassas, sendo } \\
\text { engobo vermelho e } \\
\text { incisões as mais } \\
\text { notadas. Há formas } \\
\text { fechadas e abertas, } \\
\text { em geral de contorno } \\
\text { simples e suavemente } \\
\text { infletidas, sem } \\
\text { ângulos. Muitas } \\
\text { possuem grande } \\
\text { capacidade } \\
\text { volumétrica. }\end{array}$ & $\begin{array}{l}\text { Rio Jamari, } \\
\text { afluente da } \\
\text { margem direita } \\
\text { do rio Madeira. } \\
\text { Alguns sítios no } \\
\text { rio Madeira. }\end{array}$ & $\begin{array}{l}1700-800 \\
\text { anos AP }\end{array}$ & $\begin{array}{l}\text { Tupi } \\
\text { (Tupi- } \\
\text { Arikém?) }\end{array}$ \\
\hline
\end{tabular}




\begin{tabular}{|c|c|c|c|c|}
\hline $\begin{array}{l}\text { Polícroma } \\
\text { da } \\
\text { Amazônia }\end{array}$ & $\begin{array}{l}\text { Manufatura roletada. } \\
\text { Cariapé, carvões e } \\
\text { minerais são os } \\
\text { antiplásticos mais } \\
\text { comuns. Pintura de } \\
\text { tonalidade branca e } \\
\text { uma alta variação } \\
\text { entre os vermelhos, } \\
\text { indo do vermelho- } \\
\text {-alaranjado ao } \\
\text { vermelho escuro, em } \\
\text { geral delimitadas por } \\
\text { incisões. } \\
\text { Predominância de } \\
\text { formas abertas e } \\
\text { diversas com } \\
\text { pequenos volumes. } \\
\text { Muitas formas } \\
\text { irregulares. }\end{array}$ & $\begin{array}{l}\text { Margens de rios } \\
\text { primários e } \\
\text { secundários da } \\
\text { Amazônia } \\
\text { Ocidental. }\end{array}$ & $\begin{array}{l}1300-400 \\
\text { anos AP }\end{array}$ & Tupi (Arawak) \\
\hline
\end{tabular}

Fonte: Miller, 1992; Almeida, 2013a; Zuse, 2014.

Diferentemente de boa parte dos locais onde há evidência de cerâmica Pocó na bacia amazônica, esses primeiros vestígios de povos ceramistas no rio Madeira são continuidades em uma longa e pretérita trajetória da presença indígena no local. Mesmo que em pouca quantidade, essa cerâmica, com decoração refinada e com vasos de pequenos volumes destinados ao consumo individual ou coletivo de bebidas (alcoólicas? psicotrópicas?), parece indicar a existência de um uso ritual dos lugares onde se nota sua presença.

A pouca presença de grandes potes para preparo e/ou armazenagem na indústria cerâmica Pocó do Teotônio sugere que o investimento na realização de uma cerâmica ritual voltada à relação com o mundo cosmogônico é mais importante do que uma produção para fins domésticos (cf. Neves, 2012). As datações recuadas para esse material rebuscado ( 3 mil anos AP), que surge no registro arqueológico de forma abrupta e recorrente em pontos específicos da Amazônia, reforça a impressão do uso ritual dessa cerâmica, que teria sido empregado por antigos povos de língua Arawak (Neves, 2012; Almeida, 2013a; Zuse, 2014). Além das cachoeiras, lagos e encontros de águas são as áreas em que mais se identifica esse tipo de material, remetendo à ideia de que esses grupos constantemente buscaram por lugares significativos. 
Como mudam as formas cerâmicas, pode mudar também a maneira de se estar em um lugar. Em todos os conjuntos cerâmicos posteriores há vasos de maiores volumes, de borda aberta e fechada, destinados tanto à armazenagem quanto ao preparo de alimentos. A possibilidade de o sítio Teotônio, em determinados momentos, ter traços mais característicos de espaço para habitação não implica, no entanto, uma diminuição de sua condição mítica e sagrada, mas sim uma nova forma de operar esse viés simbólico.

A própria mistura de diferentes conjuntos tipológicos cerâmicos nas mesmas camadas estratigráficas nos permite induzir que trocas e relações eram constantes entre os moradores da cachoeira e visitantes, que possivelmente vinham em função de festividades. Cerâmica de estilo Barrancoide foi identificada tanto em sítios vizinhos ao Teotônio (Zuse, 2014) como misturada ao material Pocó e Jamari desse sítio, reforçando a impressão de um contato intenso de seus habitantes com os vizinhos.

A presença de cerâmica Jamari em 1.500 anos AP no sítio Teotônio sugere a ida de grupos do rio homônimo, onde essa cerâmica possui datas de mais de 2.500 anos AP, para a calha do Madeira. Pode-se pensar que os grupos Tupi do interior - os Tupi Arikém seguem ocupando partes da bacia do Jamari -, que supostamente produziam a cerâmica Jamari (Miller, 2009), em determinado momento da história resolveram ocupar o mainstream do alto Madeira. A aparente dominância Arawak (cerâmicas Pocó e Barrancoide) nessas cachoeiras, portanto, teria sido posta em jogo com as incursões de povos de língua Tupi, saindo das drenagens secundárias para o rio Madeira.

É possível que o último e mais recente conjunto da região, relacionado à Tradição Polícroma da Amazônia (TPA), esteja então ligado a um processo de etnogênese e estilogênese (isto é, a TPA possui elementos das indústrias anteriores) resultante do contato dessas populações diferentes (Almeida, 2013a). Em outros locais em que essa indústria foi identificada, como no médio-alto Solimões, o que se nota é que ela estava ligada a populações (os Kokama e Omágua, por exemplo; cf. Carvajal, 1941[1542]) com claras influências linguísticas Tupi e Arawak (Cabral, 1995), um possível fruto da intensa dinâmica de interações nos rios amazônicos nos séculos que antecederam a chegada dos europeus.

O sítio Teotônio é uma das áreas mais meridionais da Amazônia com presença da TPA e onde há datações mais recuadas para essa Tradição, 1.300 anos AP (Almeida, 2013a). A existência de urnas funerárias na cachoeira de Santo Antônio, a primeira do Madeira, e de uma necrópole com vasos da TPA na região da cachoeira de Jirau (Zuse, 2014), mostra que os grupos produtores 
dessa cerâmica estavam agindo em espaços amplos e diversos, com áreas de atividades específicas para cada demanda social e simbólica. Viviam até o final da parte navegável (a cachoeira do Teotônio), mas usavam as partes mais inacessíveis do grande rio para enterrar os seus mortos.

As cachoeiras rio acima têm, certamente, outras histórias para contar.

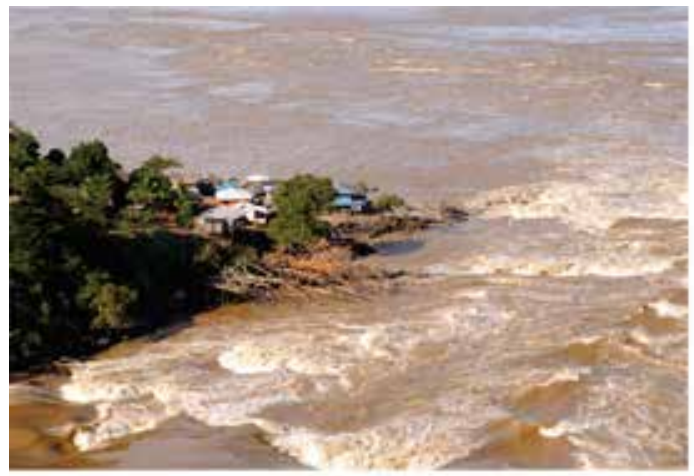

Figura 2 - A cachoeira

do Teotônio.

Foto: Wilson Dias, 2007.

Figura 3 - Vasilha cerâmica

evidenciada no sítio

Camargo, Tucuruí.

Foto: Mário Simões, 1977.
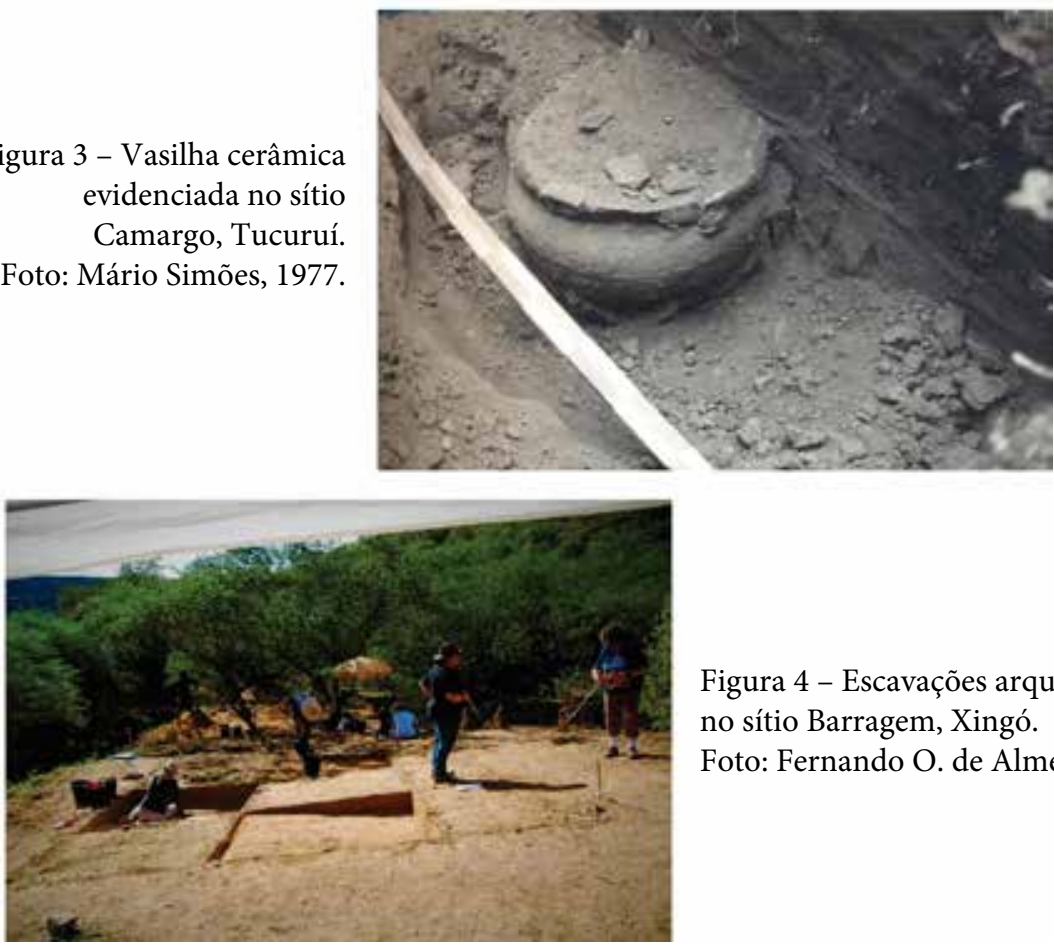

Figura 4 - Escavações arqueológicas no sítio Barragem, Xingó.

Foto: Fernando O. de Almeida, 2016. 


\section{Entre os Tupi-Guarani e os Marajoara:}

A CACHOEIRA De Tucuruí E O Baixo Tocantins

O rio Tocantins nasce na serra do Paraná, no Brasil Central. Desse ponto até a sua foz, no rio Pará, percorre cerca de 2.600 quilômetros em sentido sul-norte. A antiga cachoeira de Tucuruí, último obstáculo a ser ultrapassado pelo Tocantins, encontra-se praticamente equidistante da foz e do encontro desse rio com o Araguaia, a aproximadamente 240 quilômetros de cada. Trata-se de uma área de floresta tropical que praticamente desapareceu em razão do desmatamento. Algumas centenas de quilômetros para leste essa vegetação é substituída pela Floresta Transicional do Maranhão. Para o sul, essa vegetação se transforma no cerrado do Planalto Central. A topografia do baixo curso do rio pode ser descrita como um complexo de baixos relevos (Ab'Saber, 2004, p.94).

A cronologia para o início da ocupação humana da bacia do baixo Tocantins também possui datas bastante recuadas, do início do Holoceno (Magalhães, 2005). Dessas antigas ocupações podem-se destacar os sítios Breu Branco 1 e 2, encontrados a poucos quilômetros da cachoeira de Tucuruí, com datações que chegam a quase 11 mil anos (Caldarelli; Araújo-Costa; Kern, 2005), profundidade cronológica rara para sítios a céu aberto.

As ocupações ceramistas da bacia do baixo Amazonas são as mais antigas da América do Sul, com datas ultrapassando 7 mil anos AP para o Sambaqui de Taperinha (Roosevelt et al., 1991), 6 mil anos AP para o litoral paraense (Roosevelt, 1995), 4 mil anos AP para o interior maranhense (Almeida, 2013b) e 3 mil anos AP para o interflúvio Xingu-Tapajós (Garcia, 2016).

Durante os mais de 3 mil anos de ocupações por parte de grupos ceramistas na bacia do baixo Tocantins, o que se vê é uma ocupação tanto de áreas ribeirinhas quanto de áreas de interflúvio. Áreas de transição para o cerrado (como a Serra dos Carajás) e para a floresta maranhense foram intensamente exploradas e manejadas pelos grupos de interflúvio, gerando as chamadas florestas antropogênicas (Balée, 1994). Os sítios das drenagens secundárias e terciárias também possuem terra preta antropogênica e dimensões por vezes maiores que as dos sítios ribeirinhos (Almeida, 2016). A reocupação dos sítios de interflúvio, por grupos com indústrias cerâmicas semelhantes ou distintas, indica que os grupos indígenas não buscaram apenas áreas naturalmente atrativas, como as cachoeiras, mas também áreas transformadas por ocupações anteriores, por parentes/descendentes ou (possivelmente) inimigos.

Podemos denominar o conjunto mais antigo da bacia do baixo Tocantins, com datações atingido 3.500 anos AP, de cerâmica Inciso-Modelada. No início 
da era Cristã surge um segundo conjunto cerâmico, relacionado à Tradição Tupi-Guarani, ligado à família linguística homônima (Quadro 2). A variabilidade e profundidade cronológica do material arqueológico, assim como a diversidade das línguas Tupi-Guarani encontradas na região, permitem que se especule que foi a partir da região Xingu-Tocantins que esses grupos começaram a migrar e a se expandir para outras áreas das terras baixas sul-americanas (Almeida; Neves, 2015).

Quadro 2 - Principais agrupamentos cerâmicos da região do baixo Tocantins

\begin{tabular}{|c|c|c|c|c|}
\hline $\begin{array}{c}\text { Tradição / } \\
\text { Fase }\end{array}$ & Descrição & Localização & Cronologia & $\begin{array}{c}\text { Filiação } \\
\text { Linguística }\end{array}$ \\
\hline $\begin{array}{l}\text { Inciso- } \\
\text {-Modelada }\end{array}$ & $\begin{array}{l}\text { Manufatura por meio das técnicas } \\
\text { roletada ou modelada, com } \\
\text { antiplástico mineral ou de argila } \\
\text { moída. Alisamento fino, e paredes } \\
\text { com espessura fina (inferior a } 1 \\
\mathrm{~cm} \text { ), mesmo em vasos com grandes } \\
\text { capacidades volumétricas ( }>20 \mathrm{~L}) . \\
\text { As formas possuem contorno } \\
\text { simples ou composto, geralmente } \\
\text { com formas fechadas. Grande } \\
\text { presença de decoração incisa e } \\
\text { modelada (zoomorfa) e baixa } \\
\text { presença de pinturas. }\end{array}$ & $\begin{array}{l}\text { Áreas de } \\
\text { interflúvio } \\
\text { para leste e } \\
\text { oeste do } \\
\text { Tocantins }\end{array}$ & $\begin{array}{l}3500-? \text { anos } \\
\text { AP }\end{array}$ & $\begin{array}{l}\text { Arawak/ } \\
\text { Karib? }\end{array}$ \\
\hline $\begin{array}{l}\text { Tupi- } \\
\text {-Guarani }\end{array}$ & $\begin{array}{l}\text { Manufaturada roletada, com uso de } \\
\text { antiplástico mineral, caraipé e/ou } \\
\text { carvão. Os acabamentos de } \\
\text { superfície (alisamento) medianos. } \\
\text { A ocasional presença de grandes } \\
\text { pedaços de antiplástico mineral, } \\
\text { com comprimento maior que } 5 \\
\text { mm, ajuda a dar um aspecto mais } \\
\text { rústico a essa cerâmica. Pinturas } \\
\text { policrômicas frequentes, } \\
\text { aparecendo em motivos feitos por } \\
\text { todo o interior do vaso ou, às vezes, } \\
\text { na parte superior da face externa do } \\
\text { vaso, entre o ombro e a borda. } \\
\text { Presença de bordas vazadas. } \\
\text { Decorações incisa, corrugada e } \\
\text { ungulada. Vasos com ângulos. } \\
\text { Presença de urnas funerárias. }\end{array}$ & $\begin{array}{l}\text { libeirinhas } \\
\text { Áreas } \\
\text { ribein } \\
\text { interflúvio a } \\
\text { montante } \\
\text { de Tucuruí }\end{array}$ & $\begin{array}{l}1800-350 \\
\text { anos AP }\end{array}$ & $\begin{array}{l}\text { Tupi- } \\
\text {-Guarani }\end{array}$ \\
\hline
\end{tabular}




\begin{tabular}{|c|c|c|c|c|}
\hline Tauá & $\begin{array}{l}\text { Manufaturada roletada, com uso de } \\
\text { antiplástico mineral, caco moído e } \\
\text { caraipé. O tratamento de superfície } \\
\text { em geral era refinado, e a } \\
\text { decoração, quando presente, possui } \\
\text { grande variabilidade: pinturas } \\
\text { policrômicas, decorações plásticas, } \\
\text { com grande quantidade de motivos } \\
\text { incisos, filetes aplicados, e de } \\
\text { figuras zoomorfas. Presença de } \\
\text { bordas vazadas e urnas funerárias. } \\
\text { As paredes com média de } 0,8 \mathrm{~cm} \text {. } \\
\text { Algumas formas apresentaram } \\
\text { carenas ou ombros, mas a maioria } \\
\text { possuía contorno simples ou } \\
\text { infletido. As formas fundas, com } \\
\text { formato esférico ou semiesférico. }\end{array}$ & $\begin{array}{l}\text { Áreas } \\
\text { ribeirinhas } \\
\text { a jusante de } \\
\text { Tucuruí }\end{array}$ & 950 anos AP & ? \\
\hline Marajoara & $\begin{array}{l}\text { Manufatura roletada, antiplático de } \\
\text { caco moído. Tratamento de } \\
\text { superfície extremamente refinado. } \\
\text { Imensa quantidade de combinações } \\
\text { de decorações plásticas. Pintura } \\
\text { policrômica combinada ou não } \\
\text { com decoração plástica. Presença } \\
\text { de apliques zoomorfos e/ou } \\
\text { antropomorfos. Vasos com forma } \\
\text { zoo/antropomorfa (urnas } \\
\text { funerárias). Presença de tigelas } \\
\text { quadrangulares. Presença de bordas } \\
\text { vazadas. Além dos vasos, pode-se } \\
\text { destacar a presença de estatuetas e } \\
\text { tangas cerâmicas. Vasos com } \\
\text { capacidades volumétricas variando } \\
\text { de muito pequena }(<1 \mathrm{~L}) \text { a muito } \\
\text { grande ( }>40 \mathrm{~L}) \text {. }\end{array}$ & $\begin{array}{l}\text { Ilha de } \\
\text { Marajó e } \\
\text { arredores }\end{array}$ & $\begin{array}{l}1500-600 \\
\text { anos AP }\end{array}$ & Arawak? \\
\hline
\end{tabular}

Fonte: Simões; Araújo-Costa, 1987; Almeida, 2013a; Garcia, 2016.

Pode-se pensar, com base na análise e datação dos sítios arqueológicos, que, por volta de mil anos AP, o encontro dos rios Tocantins e Araguaia era um grande núcleo de ocupação dos Tupi-Guarani (Almeida, 2016). Para essa mesma época, essa "homogeneidade cultural" Tupi-Guarani presente no encontro dos rios Araguaia e Tocantins não pode ser identificada rio abaixo, na 
cachoeira de Tucuruí. Pelo contrário, o que se encontra ali é uma imensa confusão estilística.

O primeiro estudioso a descrever o material arqueológico de Tucuruí foi Nimuendajú (2000), que chegou a escavar sítios na região a jusante da cachoeira de Tucuruí nos anos 1930. Da passagem do etnólogo pelo local fica a relação que ele especula existir entre a cerâmica local e a famosa cerâmica Marajoara, o que não chega a ser uma surpresa, lembrando que o Tocantins deságua justamente na ilha de Marajó.

A fase mais intensa de pesquisas em Tucuruí começou em 1976 e continuou nos anos seguintes, quando o Museu Goeldi foi incumbido da pesquisa na área a ser impactada pela construção da hidrelétrica de Tucuruí (Simões; Araújo-Costa, 1987). Dentre o material escavado pode-se destacar a chamada fase Tauá, encontrada no entorno (especialmente abaixo) da cachoeira.

Os sítios da fase Tauá foram, em geral, encontrados em terraços em topo de barranco e possuíam material disposto ao longo das margens do rio (isto é, trata-se da indústria de grupos ribeirinhos), de forma paralela a ele. O material arqueológico, associado à terra preta antropogênica, foi encontrado a $70 \mathrm{~cm}$ de profundidade em dois sítios. Foram identificados sepultamentos secundários em urnas. O material lítico era composto por lâminas de machado (picotadas ou polidas), raspadores, facas e batedores (Simões; Araújo-Costa, 1987). Foi obtida uma única data para essa fase, 950+-70 AP.

No momento de classificar a fase Tauá ocorre uma divergência interpretativa. Simões e Araújo-Costa (1987) indicam que seria um estilo que combina elementos da cerâmica da Tradição Tupi-Guarani e elementos da Tradição Inciso-Ponteada. Em revisões posteriores, entretanto, Meggers (1992) e Miller et al. (1992) seguem Nimuendajú ao ligar a cerâmica Tauá à cerâmica Marajoara. Os autores acreditavam que ambas as indústrias pertenciam à Tradição Polícroma da Amazônia.

As formas dos vasos Tauá são realmente muito parecidas com as da Tradição Tupi-Guarani, incluindo a presença de vasos para o preparo e consumo de bebidas fermentadas em ambas as indústrias. Entretanto, a cerâmica Tupi-Guarani possui vasos com contornos complexos ausentes na cerâmica Tauá que, por sua vez, possui uma variedade muito maior de decorações plásticas (Almeida, 2013a). Dentre elas, podem-se destacar os apliques modelados presentes na fase Tauá. O que parece crucial, nesse sentido, é a ausência de modelados antropomorfos, incluindo vasilhas antropomorfizadas - o que seria esperado de uma fase ligada ao contexto Marajoara. Da mesma forma, alguém que compara os modelados zoomorfos e, em especial, os filetes aplicados 
ponteados da fase Tauá com a fase Marajoara e com o antigo material Inciso-Modelado regional descrito por Garcia (2016) e Almeida (2013b), com certeza verá semelhança muito maior com o contexto Inciso-Modelado. O próprio repertório reduzido de formas, encontrado na fase Tauá e nos estudos desses dois autores, parece aproximar mais a fase Tauá dos elementos da cerâmica antiga Inciso-Modelada do que do sofisticado repertório Marajoara.

Todavia, um elo que liga a cerâmica Tauá às cerâmicas Marajoara e Tupi-Guarani da Amazônia é a presença dos chamados vasos chocalhos. Trata-se de tigelas, geralmente com decorações pintadas e/ou plásticas, que possuem a borda vazada, dentro da qual se colocavam, por exemplo, cacos triturados de cerâmica. O movimento rítmico do vaso geraria o som de um chocalho. Os elementos de decoração e o som de chocalho denotam uma característica ritual desses vasos. Um ritual que, levando em conta a presença e dispersão desse tipo de vaso, estaria difundido por todo o baixo Tocantins, incluindo o lugar onde os estilos (e as pessoas) se encontravam, na cachoeira de Tucuruí.

Ao que tudo indica, durante o período pré-colonial a cachoeira de Tucuruí foi uma área de encontro de grupos Tupi-Guarani, de grupos produtores de cerâmica Incisa-Modelada (Karibe?) e de grupos da Ilha de Marajó (Arawak?). Um reflexo dessa história de interações pode ser observado na cerâmica Tauá, de difícil classificação. Apesar de a cronologia ser insuficiente para estipular o começo e o fim da ocupação dos ceramistas da fase Tauá, é bem provável que esses grupos ribeirinhos tenham sido dos primeiros a sofrer com o impacto da chegada dos europeus, os quais subiram o Tocantins desde Belém (Kiemen, 1973).

Com o início do período colonial, o que se observa é o abandono das áreas ribeirinhas do baixo Tocantins por parte dos grupos indígenas. Documentos mostram que a "terra tupinambá" do Tocantins-Araguaia seria amplamente explorada pelos colonos europeus a partir de Belém, desde o início do século XVII (Vieira, 1997 [1655-1659]). Ocorre também uma mudança nos protagonistas. Enquanto muitos grupos Tupi-Guarani se refugiam dos europeus nas áreas de interflúvio, não há documentação que indique a presença de grupos Karibe ou Arawak na região. Os Tupi-Guarani passam a conviver com uma série de grupos Jê empurrados do Brasil Central (os Kayapó, por exemplo) e do Maranhão (os Timbira, entre outros) pela frente colonial (Laraia; Da Mata, 1967). Momento em que a cachoeira de Tucuruí perde seu status de ponto de encontro pelos coletivos indígenas. 


\section{Do Sertão para o Mar: as CORREdeiras DE Xingó E o baixo São Francisco}

O rio São Francisco se estende por mais de 2.100 quilômetros, corre predominantemente em sentido sul-norte e, no trecho final, oeste-leste. Sua última corredeira, ${ }^{3}$ Xingó, encontrava-se a aproximadamente 200 quilômetros da foz do rio, no oceano Atlântico. Desde a sua nascente no altiplano da Serra da Canastra (MG) até sua foz no Atlântico, na divisa entre Alagoas e Sergipe, o rio é um caminho fluvial que liga as regiões Sudeste e Nordeste do País, o Brasil Central ao litoral. Atravessa vegetações tropicais úmidas de planalto, cerrados e, especialmente, de caatinga (Ab'Saber, 2006).

Por grande parte de sua extensão, o São Francisco é um rio perene solitário, uma vez que muitas veredas que o abastassem, após atravessar extensas áreas de depressões interplanálticas, maciços antigos e chapadas, desaparecem durante o longo período seco do ano (Ab’Saber, 1999). Por quilômetros a jusante de Xingó, o rio corre encaixado em relevo íngreme, por vezes cânions. Nesse terreno abrupto, a ocasional presença de áreas planas - os terraços fluviais - sugere a presença humana no passado e no presente. É provável, dadas essas condições topográficas, que as habitações indígenas possuíssem padrão semelhante aos das atuais casas das populações ribeirinhas: linear (ou linhas de casas), paralela(s) ao rio.

A maior intensidade das pesquisas arqueológicas realizadas na região ocorreu a partir do fim dos anos 1980, com o início das obras para a construção da UHE (Usina Hidrelétrica) Xingó, e foram realizadas por quase 20 anos. Tais pesquisas fornecem a base para que se possa visualizar uma consistente, ainda que incompleta, história de ocupação indígena regional.

A presença de populações humanas na região do médio-baixo São Francisco data de mais de 9 mil anos AP para Xingó (Carvalho, 2007) e 7 mil AP para a gruta do Padre, em Itaparica (Martin, 2005). A presença de cemitérios (Vergne, 2007), com grande quantidade e variedade de enterramentos (em torno de 150 escavados na necrópole do Justino), objetos de indumentária (braceletes e colares de ossos e tembetás líticos, por exemplo) (Carvalho, 2007), e sítios com pinturas rupestres (Amâncio-Martinelli, 1997), são consistentes indicadores de que esses grupos possuíam uma sofisticada vida ritual.

Um dos elementos que chamam atenção na região nesse universo ritualístico pré-colonial de Xingó é a existência de fluxos distintos de movimentos. Por exemplo, alguns terraços fluviais, como é o caso do já citado sítio Justino, foram transformados em cemitérios, possivelmente sediando 
rituais com a presença de grupos interioranos e de outros trechos do rio. Ao mesmo tempo, a existência de conjuntos de abrigos com pinturas e gravuras rupestres em drenagens secundárias, no entorno de Xingó, indica que o complexo ritualístico dos ribeirinhos também ocorria em áreas discretas, longe do olhar do São Francisco. Economicamente, pode-se especular que a persistente tradição sertaneja de fazer acampamentos de caça (terrestre) nas drenagens secundárias remonte a um passado longínquo, uma maneira de quebrar com o provável monopólio do alimento "aquático" na vida das margens do São Francisco.

A região Nordeste brasileira também possui algumas das cerâmicas mais antigas da América do Sul, como a Tradição Pedra do Cabloco, com 2.800 anos, e Xingó, com mais de 4 mil anos (Luna, 2006). A cerâmica de Xingó é um enigma para os arqueólogos, tanto por causa da sua imensa profundidade temporal (+- 4 mil anos AP) quanto pelo fato de essa cerâmica possuir características regionais, não tendo sido identificada em outros contextos. Os vasilhames têm formas simples, com poucas decorações, e com pasta escura. Alguns fatores chamam a atenção sobre esse material, como a presença antiga de artefatos cerâmicos cerimoniais, com os vasos utilizados em rituais mortuários (enterramentos primários e secundários). Assim como no caso do Teotônio e de Tucuruí, o que se percebe na cerâmica de Xingó é uma heterogeneidade estilística (Quadro 3), parte da qual pode ser fruto do contato com os diferentes grupos que circulavam pelo lugar. A análise da composição química dos artefatos cerâmicos corrobora esse cenário (Munita; Barroso; Oliveira, 2006). Ao contrário dos outros dois casos aqui discutidos, não é possível identificar conjuntos de vasos relacionados ao preparo e ao consumo de fermentados. Nesse sentido, a presença de cachimbos cerâmicos nos sítios cerimoniais pode ser um indício de que os rituais ali realizados estariam muito mais ligados ao consumo de tabaco do que ao consumo de bebidas alcoólicas - cenário condizente com o que é descrito pela etnografia Jê do Brasil Central.

Existe grande dificuldade, decorrente da antiguidade e intensidade do processo colonizador no Nordeste, em tecer relações entre o contexto arqueológico e os contextos etno-históricos/linguísticos. As línguas dos Xocó, Pankararú, Kariri e diversos outros grupos indígenas regionais, muitos dos quais participaram ativamente da chamada Guerra dos Bárbaros durante a segunda metade do século XVII (Puntoni, 2002), foram irremediavelmente afetadas pela presença colonial. Ainda assim, os dados linguísticos existentes (Urban, 1992, p.90) apontam que o médio-baixo São Francisco seria uma 
região predominantemente Macro-Jê. Seria, portanto, na região de entorno desse rio que esses grupos teriam começado a se espalhar, mais ou menos 5 mil anos atrás. A proximidade dessa estimativa com relação ao surgimento da cerâmica em Xingó permite que se especule sobre a relação entre os contextos linguísticos e arqueológicos. Diante dessa perspectiva, a região de Xingó torna-se área-chave para a compreensão da história antiga dos grupos Macro-Jê.

Um dos possíveis problemas interpretativos da cerâmica de Xingó é que ela tem sido vista como um todo heterogêneo, ao invés de uma série de conjuntos menores, espalhados no tempo e no espaço. Se separarmos, por exemplo, apenas os vasos rituais utilizados no cemitério do Justino, é possível identificar algumas semelhanças estilísticas com as cerâmicas Una encontradas no alto São Francisco e, em menor grau, com as cerâmicas Itararé-Taquara identificadas na região sul do país e em São Paulo: paredes finas, antiplástico mineral, predileção por pastas escuras, formas simples, bases aplainadas (por vezes côncavas). Caso confirmada essa relação, e a maior profundidade temporal do Nordeste (4 mil anos AP) frente ao Sudeste e ao Sul (2 mil anos AP), seria possível visualizar o rio São Francisco como um dos principais caminhos pelos quais os grupos Macro-Jê se expandiram pelas terras baixas brasileiras.

Entretanto, os grupos Macro-Jê deviam receber visitas com frequência. Os Tupinambá, de língua Tupi-Guarani, seriam os últimos grupos indígenas a entrarem no Nordeste, por volta de 900 d.C. Os relatos produzidos por Gabriel Soares de Souza (2001 [1587]) condizem com um panorama de intensa interação entre esses grupos e os que os antecederam na região. O cronista sugere que o rio São Francisco foi uma rota utilizada por grupos de língua Tupi-Guarani para a conquista de grande extensão do litoral nordestino até então ocupado, segundo o cronista, por grupos Tapuias (isto é, prováveis grupos de língua Jê). Chama a atenção nesse relato o caráter dual do baixo São Francisco, ora servindo como ligação entre sertão e mar, ora servindo como "fronteira" entre os Tupinambá e os Caeté - assim como hoje o faz com relação aos estados de Alagoas e Sergipe. 
Quadro 3 - Principais agrupamentos cerâmicos da região do médio-baixo São Francisco

\begin{tabular}{|c|c|c|c|c|}
\hline $\begin{array}{l}\text { Tradição / } \\
\text { Fase }\end{array}$ & Descrição & Localização & Cronologia & $\begin{array}{c}\text { Filiação } \\
\text { Linguística }\end{array}$ \\
\hline Xingó & $\begin{array}{l}\text { Cerâmica acordelada e/ou } \\
\text { modelada, com } \\
\text { antiplástico de areia; } \\
\text { formas pequenas e } \\
\text { médias, com contorno } \\
\text { simples aberto. A queima } \\
\text { é redutora, com paredes } \\
\text { escuras. Decorações } \\
\text { incisas, escovadas, } \\
\text { corrugadas (raras). } \\
\text { Presença de cachimbos } \\
\text { cerâmicos. Existem urnas } \\
\text { Funerárias e cerâmicas } \\
\text { associadas a } \\
\text { enterramentos primários. }\end{array}$ & $\begin{array}{l}\text { Cachoeira } \\
\text { de Xingó }\end{array}$ & $\begin{array}{l}4000-500 \\
\text { AP }\end{array}$ & Macro-Jê? \\
\hline $\begin{array}{l}\text { Tupi-Guarani } \\
\text { (Tupinambá) }\end{array}$ & $\begin{array}{l}\text { Acordelada, com } \\
\text { antiplástico de areia ou } \\
\text { caco moído. Vasos com } \\
\text { grande diversidade } \\
\text { morfológica (presença de } \\
\text { ângulos), de decorações } \\
\text { plásticas (corrugados, } \\
\text { ungulados, incisos) e } \\
\text { pinturas (vermelho, preto } \\
\text { e branco). }\end{array}$ & $\begin{array}{l}\text { Foz do São } \\
\text { Francisco (?) }\end{array}$ & $\begin{array}{l}1100-400 \\
\text { AP }\end{array}$ & $\begin{array}{l}\text { Tupi- } \\
\text { Guarani }\end{array}$ \\
\hline Cabrobó & $\begin{array}{l}\text { Acordelada, com } \\
\text { antiplástico de areia, } \\
\text { decoração corrugada } \\
\text { ungulada, espatulada e } \\
\text { acanalada. Vasilhas } \\
\text { esféricas e semiesféricas, } \\
\text { com contorno simples, } \\
\text { com capacidade } \\
\text { volumétrica média ou } \\
\text { grande. }\end{array}$ & $\begin{array}{l}\text { Ilhas do } \\
\text { Médio São } \\
\text { Francisco }\end{array}$ & ? & ? \\
\hline
\end{tabular}

Fonte: Luna, 2006. 
É possível perceber a presença dos Tupinambá rondando o baixo São Francisco em elementos exóticos identificados na cerâmica, como pontual presença de decoração corrugada, mas não é possível mapear formalmente tal existência. Ainda não foram identificados sítios Tupinambá nessa região. A influência Tupinambá também é vista nas ilhas do médio São Francisco, onde foram identificadas urnas funerárias globulares (comuns às cerâmicas Jê) cobertas com os tradicionais corrugados Tupinambá (Oliveira, 2016). Resta saber, nesse caso ainda não datado, se essa combinação de elementos está relacionada ao período pré-colonial ou se resulta do agrupamento de diferentes coletivos nas missões jesuíticas que foram erguidas nas mesmas ilhas ou em suas proximidades, durante o início do período colonial (cf. Nantes, 1979). Se pensarmos nas ilhas fluviais dos mais diversos contextos também como potenciais lugares significativos, seremos obrigados a não descartar a hipótese de que se trata de um fenômeno pré-colonial.

\section{DiscUSsão FINAL}

As cachoeiras são lugares de vida, permanência, passagem e morte. A heterogeneidade arqueológica desses lugares, como foi possível constatar nos exemplos apresentados, claramente sugere que esses lugares, menos do que áreas que delimitam a presença de determinados coletivos (cf. Meggers et al., 1988), foram entroncamentos para o encontro de populações indígenas durante centenas ou mesmo milhares de anos.

Os diferentes contextos apresentados permitem vislumbrar a potencialidade da discussão do protagonismo histórico dos povos indígenas da América do Sul por meio das cachoeiras. É claro que as cachoeiras não são os únicos possíveis lugares significativos e persistentes, os únicos bolsões de histórias. Ilhas fluviais e litorâneas, encontros de rios, serras, são exemplos de outros lugares que podem deter esse status. A carta escrita pelos Muduruku em 2013, ${ }^{4}$ na luta contra a construção das hidrelétricas nas cachoeiras dos rios Tapajós e Teles Pires, é um documento no qual se pode claramente compreender a significância dessas diferentes áreas para os coletivos indígenas (Pugliese Jr.; Valle, 2015). Da mesma forma, áreas a priori sem atrativos, mas modificadas pelos seres humanos, como as florestas antropogênicas descritas anteriormente ou as estruturas de terra (geoglifos) encontradas no sudoeste da Amazônia, também podem virar lugares persistentes (Almeida, 2017).

Tampouco se trata de um fenômeno sul-americano. O poder de encantamento desses monumentos naturais parece ser universal à história humana no 
planeta. As densas e politicamente hierarquizadas sociedades indígenas que viviam da pesca (de salmão) e da coleta nas cachoeiras e corredeiras da região sudoeste do Canadá parecem um exemplo claro disso (Cannon, 1999). Os sítios neolíticos de Abu Rureyra (Síria), com mais de 6 mil anos de ocupação (13.400 - 7.500 anos AP), também (Moore, 2014).

Como se pode ver nos exemplos fornecidos, por mais que esses locais sejam universais, acomete-se sobre eles uma cegueira parcial. Sem o crivo da história ou da arqueologia, o próprio lugar é relegado, destituído das existências que o constituíram. Fadados a marcá-los com as cicatrizes do nosso tempo, não apenas alteramos seu nome ou o uso que deles fazemos. Criamos uma ferida mais profunda, que os faz, por fim, desaparecer.

Se foi possível apontar algumas histórias, outras muitas estarão fadadas a ficar para sempre debaixo d'água ou aniquiladas por um canteiro de obras. A arqueologia possui uma irônica e contraditória relação com esses lugares, visto que muitas vezes é a destruição deles que leva à produção de conhecimento sobre as sociedades que por milhares de anos habitaram esses lugares. É imperativo, portanto, modificar essa relação: reforçar o caráter diferenciado desses lugares, seja para que os estudos de licenciamento sejam ainda mais cuidadosos, seja para que tais lugares sejam conservados, de maneira a preservar as histórias ali contidas, respeitando as populações que os utilizam para suas vidas e como meio para compreender o mundo.

\section{Agradecimentos}

Agradecemos ao CNPq e à Fapesp o financiamento de parte desta pesquisa. Os trabalhos amazônicos aqui apresentados ocorreram dentro do Arqueotrop (MAE-USP), em coordenação conjunta com o professor doutor Eduardo Góes Neves. As pesquisas no baixo São Francisco fazem parte de um projeto recentemente iniciado com as professoras doutoras Daniela Klokler e Brenda J. Bowser na região pelo Laboratório de Paisagem e Sociedade (LAPSO-UFS). A datação da fase Tauá foi gentilmente cedida por Celso Perota a Bruna Rocha que, por sua vez, concedeu-nos o direito de uso. Jaqueline Carou realizou a revisão. A eles e aos nossos colegas de laboratórios, nossos agradecimentos. 


\section{REFERÊNCIAS BIBLIOGRÁFICAS}

AB’SABER, Aziz N. Amazônia: do Discurso à Práxis. São Paulo: Edusp, 2004. Brasil, paisagens de exceção: o litoral e o pantanal mato-grossense, patrimônios básicos. São Paulo: Ateliê Editorial, 2006. . Sertões e sertanejos: uma geografia humana sofrida. Estudos avançados, São Paulo: Instituto de Estudos Avançados/USP, v.13, n.36, p.7-59, 1999.

ABREU, J. Capistrano de. Caminhos antigos e povoamento do Brasil. São Paulo: Edusp, 1989.

ALMEIDA, Fernando O. Arqueologia dos Tupi-Guarani no Baixo Amazonas. In: BARRETO, Cristiana; LIMA, Helena P.; BETANCOURT, Carla J. (Org.) Cerâmicas Arqueológicas da Amazônia: rumo a uma nova síntese. Belém, PA: Ministério da Cultura/Iphan/Museu Paraense Emílio Goeldi, 2016. v.1, p.171-182.

. Cerâmica Antiga na Periferia Leste da Amazônia: o sítio Remanso/MA. Amazônica (Revista de Antropologia), Belém: UFPA, p.72-96, $2013 \mathrm{~b}$.

The Organics of Settlement Patterns in Amazonia. In: KELLET, Lucas C.; JONES, Eric (Ed.) Settlement Ecology of Ancient the Americas. New York: Routledge, 2017. p.278-312.

. A Tradição Polícroma no Alto Rio Madeira. Tese (Doutorado em Arqueologia)

- Museu de Arqueologia e Etnologia, Universidade de São Paulo (USP). São Paulo, 2013a.

ALMEIDA, Fernando O.; NEVES, Eduardo G. Evidências Arqueológicas para a Origem dos Tupi-Guarani no Leste da Amazônia. Mana, Rio de Janeiro: PPGAS/ UFRJ, v.21, n.3, p.499-525, 2015.

AMÂNCIO-MARTINELLI, Suelly. Arte Rupestre em Xingó. Cadernos de Arqueologia, Canindé de São Francisco: PAX/UFS, 1997.

BALÉE, W. Footprints of the Forest: Ka'apor Ethnobotany - the historical ecology of plant domestication by an Amazonian people. New York: Columbia University Press, 1994.

BRAUDEL, Fernand. História e Ciências Sociais. Trad. Rui Nazaré. Lisboa: Presença, 1990.

CABRAL, Ana Suelly A. C. Contact Induced Language Change in the Western Amazon: The Non-Genetic Origin of the Kokama Language. Dissertation ( $\mathrm{PhD}$ in Linguistics) - University of Pittsburgh. Pittsburgh, PA, USA, 1995.

CALDARELLI, Solange B.; ARAÚJO-COSTA, Fernanda de; KERN, Dirse C. Assentamentos a céu aberto de caçadores-coletores datados da transição Pleistoceno Final / Holoceno Inicial no sudeste do Pará. Revista de Arqueologia, São Paulo: SAB, v.18, p.95-108, 2005.

CARVAJAL, Frei Gaspar de. Descobrimento do Rio Amazonas. [1542]. São Paulo: Cia. Ed. Nacional, 1941. 
CARVALHO, Olívia A. Bioanthopologie des Nécropoles de Justino et de São José II, Xingó, Brésil. Canindé do São Francisco: Museu de Arqueologia de Xingó, 2007.

CLEMENT, Charles R. 1492 and the Loss of Amazonian Crop Genetic Resources I: the relation between domestication and human population decline. Economic Botany, New York: The New York Botanical Garden, v.53, n.2, p.188-202, 1999.

CORRÊA, Ângelo A. Longue durée: história indígena e arqueologia. Ciência e Cultura, Campinas: SBPC, v.65, n.2, p.26-29, 2013.

FEIT, Harvey A. Introduction: North America. In: LEE, Richard B.; DALY, Richard (Org.) The Cambridge Encyclopedia of Hunter-Gatherers. Cambridge: Cambridge University Press, 1999. p.23-30.

FONSECA, João Severiano da. Viagem ao redor do Brasil (1875-1878). v.1. Rio de Janeiro: Typographia de Pinheiro \& C., 1881.

GARCIA, Lorena. Cerâmicas e Histórias Indígenas no médio-baixo Xingu. In: BARRETO, Cristiana; LIMA, Helena P.; BETANCOURT, Carla J. (Org.) Cerâmicas Arqueológicas da Amazônia: rumo a uma nova síntese. Belém: Ministério da Cultura/Iphan/Museu Paraense Emílio Goeldi, 2016. v.1, p.183-195.

GINZBURG, Carlo. O fio e os rastros: verdadeiro, falso, fictício. Trad. Rosa Freire d'Aguiar e Eduardo Brandão. São Paulo: Companhia das Letras, 2007.

GOLDSTEIN, Ilana S. Iauretê Cachoeira das Onças: um registro fílmico de patrimônio imaterial. Revista Proa, Campinas: Unicamp, v.1, n.1, p.334-342, 2009.

GONZÁLEZ RUIBAL, Alfredo. The Past is Tomorrow: Towards an Archaeology of the Vanishing Present. Norwegian Archaeological Review, Oxford: Taylor \& Francis, v.39, n.2, p.110-125, 2006.

GOULDING, Michael; SMITH, Nigel; MAHAR, Dennis J. Floods of Fortune: Ecology \& Economy Along the Amazon. New York: Columbia University Press, 1996.

HARNER, Michael. The Jivaro: people of the Sacred Waterfalls. Berkeley, Los Angeles, London: University of California Press, 1972.

HECKENBERGER, Michael J. Estrutura, história e transformação: a cultura xinguana no longue durée, 1000-2000 d.C. In: FRANCHETTO, Bruna; HECKENBERGER, Michael B. (Org.) Os povos do Alto Xingu: história e cultura. Rio de Janeiro: Ed. UFRJ, 2001.

KIEMEN, Mathias C. The Indian Polity of Portugal in the Amazon Region, 1641-1693. New York: Octagon Books, 1973.

LARAIA, Roque B.; DA MATA, Roberto A. Índios Castanheiros: a empresa extrativista e os índios do médio Tocantins. São Paulo: Difel, 1967. (Col. Corpo e Alma do Brasil).

LUNA, Sueli. As Pesquisas Arqueológicas sobre Cerâmica no Nordeste do Brasil. Revista Canindé, Canindé de São Francisco: MAX/UFS, v.8, p.167-207, 2006.

MAGALHÃES, Marcos. A Phyisis da Origem: o sentido da história na Amazônia. Belém: Museu Paraense Emílio Goeldi, 2005. 
MARTIN, Gabriela. Pré-História do Nordeste do Brasil. Recife: Ed. Universitária/UFPE, 2005.

MAUSS, Marcel. Ensaio sobre a dádiva: forma e razão da troca nas sociedades arcaicas. 2012. Repositório UFSC. Disponível em: http://repositorio.ufsc.br/xmlui/handle/123456789/1888; Acesso em: 20 abr. 2017.

MEGGERS, Betty J. Prehistoric Population Density in the Amazon Basin. In: VERUNO, John W.; UBELAKER, Douglas H. (Org.) Disease and Demography in the Americas. Washington, D.C.: Smithsonian Institution Press, 1992. p.197-205. . et al. Implications of Archaeological Distributions in Amazonia. In: HEYER, W. Ronald; VANZOLINI, Paulo E. (Org.) Proceedings of a Workshop of Neotropical Distribution Patterns. Rio de Janeiro: Academia Brasileira de Ciências, 1988. p.275-294.

MENÉNDEZ, Miguel. Uma contribuição para a etno-história da área Tapajós-Madeira. Revista do Museu Paulista, São Paulo: USP, v.28, p.289-388, 1981.

MILLER, Eurico T. Adaptação agrícola Pré-Historica no Alto Rio Madeira. In: MEGGERS, Betty J. (Org.) Prehistoria Sudamericana: nuevas perspectivas. Washington, D.C.: Taraxacum, 1992.

. A Cultura Cerâmica do Tronco Tupi no alto Ji-Paraná, Rondônia, Brasil: algumas reflexões teóricas, hipotéticas e conclusivas. Revista Brasileira de Linguística Antropológica, v.1, n.1, p.35-136, 2009.

. et al. Arqueologia nos empreendimentos hidrelétricos da Eletronorte. Brasília: Eletronorte, 1992.

MONGELÓ, Guilherme, Z. O formativo e os modos de produção: ocupações pré-ceramistas no Alto Rio Madeira-RO. Dissertação (Mestrado em Arqueologia) - Museu de Arqueologia e Etnologia, Universidade de São Paulo (USP). São Paulo, 2015.

MOORE, Andrew M. T. Abu Hureyra: Agriculture and Domestication. In: SMITH, Claire (Ed.) Encyclopedia of Global Archaeology. New York: Springer, 2014. p.1-3.

MUNITA, Casimiro S.; BARROSO, Lúcia P.; OLIVEIRA, Paulo M. S. Stopping rule for variable selection using stepwise discriminant analysis. Journal of Radioanalytical and Nuclear Chemistry, v.269, n.2, p.335-338, 2006.

NANTES, Martinho. Relação de uma missão no rio São Francisco: relação sucinta e sincera da missão do padre Martinho de Nantes, pregador capuchinho, missionário apostólico no Brasil entre os índios chamados cariris. São Paulo: Cia. Ed. Nacional, 1979.

NEVES, Eduardo G. Sob os Tempos do Equinócio: oito mil anos de história na Amazônia Central (6500 a.C. - 1500 d.C.). Tese (Livre-Docência) - Museu de Arqueologia e Etnologia, Universidade de São Paulo (USP). São Paulo, 2012.

NIMUENDAJÚ, Curt. Cartas do Sertão: de Curt Nimuendaju a Carlos Estevão Oliveira. Lisboa: Museu Nacional de Etnologia; Assírio e Alvim, 2000. 
OLIVEIRA, Jéssica R. Os habitantes do rio São Francisco e as missões religiosas no Sertão Pernambucano: uma paisagem fluvial do rio São Francisco - Orocó. Dissertação (Mestrado em Arqueologia) - Departamento de Arqueologia, Universidade Federal de Sergipe (UFS). Laranjeiras, 2016.

ORWELL, George. 1984. Trad. Alexandre Hubner e Heloisa Jahn. São Paulo: Companhia das Letras, 2009.

PUGLIESE JR., Francisco A.; VALLE, Raoni B. M. A gestão do patrimônio arqueológico em territórios indígenas: a resistência Munduruku e a preservação do patrimônio cultural frente ao Licenciamento ambiental de empreendimentos em territórios tradicionalmente ocupados. Revista de Arqueologia, São Paulo: SAB, v.28, n.1, p.30-51, 2015.

PUNTONI, Pedro. A Guerra dos Bárbaros. São Paulo: Edusp, 2002.

RODRIGUES, Aryon D.; CABRAL, Ana Suelly A. C. 'Tupían'. In: CAMPBELL, Lyle; GRONDONA, Verónica (Org.) The indigenous languages of South America: a comprehensive guide (v.2). Berlin, New York: Walter de Gruyter, 2012. p.495-574.

ROOSEVELT, Anna C. Early Pottery in the Amazon: twenty years of scholarly obscurity. In: BARNETT, William K.; HOOPES, John W. (Org.) The Emergence of Pottery: technology and innovation in ancient societies. Washington, London: Smithsonian Institution Press, 1995. p.115-131.

et al. Eighth Millennium Pottery from Prehistoric Shell Midden in the Brazilian Amazon. Science, Washington, D.C.: AAAS, v.254, p.1621-1624, 1991.

RUSSELL, Lynette. Remembering Places Never Visited: Connections and Context in Imagined and Imaginary Landscapes. International Journal of Historical Archaeology, New York: Springer, v.16, n.2, Archaeology, Memory, and Oral Tradition, p.401-417, June 2012.

SAMMARK, Alexandra; SEMPLE, Sarah. Topography of outdoor assembly in Europe with reference to recent field results from Sweden. In: LEWIS, Helen; SEMPLE, Sarah (Ed.) Perspectives in Landscape Archaeology: Papers presented at Oxford 2003-5. Oxford: BAR International Series, Hadrian Books, 2010.

SANTOS, Milton. A natureza do espaço. São Paulo: Edusp, 2002.

. Pensando o espaço do homem. São Paulo: Edusp, 2004. . Da totalidade ao lugar. São Paulo: Edusp, 2005.

SAQUET, Marcos A. Por uma abordagem territorial. In: SAQUET, Marcos A.; SPOSITO, Eliseu S. (Org.) Territórios e territorialidades: teorias, processos e conflitos. São Paulo: Expressão Popular, 2009.

SIMÕES, Mário F.; ARAÚJO-COSTA, Fernanda. Pesquisas Arqueológicas no Baixo Rio Tocantins (Pará). Revista de Arqueologia, Belém: SAB, v.4, n.1, p.11-27, 1987. SOUZA, Gabriel S. Tratado Descritivo do Brasil em 1587. [1587]. Belo Horizonte: Itatiaia, 2001. 
TIZUKA, Michelle M. Geoarqueologia e paleoidrologia da planície aluvial holocênica do alto Rio Madeira entre Porto Velho e Abunã-RO. Dissertação (Mestrado em Geologia) - Instituto de Geociências e Ciências Exatas, Universidade Estadual Paulista "Júlio de Mesquita Filho" (Unesp). Rio Claro, 2013.

URBAN, Greg. A história da cultura brasileira segundo as línguas nativas. In: CUNHA, Manuela C. da. História dos índios no Brasil. São Paulo: Companhia das Letras, 1992. p.87-102.

VERGNE, Maria C. S. Complexidade social e ritualidade funerária em Xingó: apontamentos teóricos para compreensão das práticas mortuárias do Sítio Justino, Canindé de São Francisco - SE. Revista Canindé, Canindé de São Francisco: MAX/ UFS, v.9, p.25-58, 2007.

VIEIRA, Antônio. Cartas (v.1). [1655 a 1659]. AZEVEDO, J. L. (Org.) Biblioteca de Autores Portugueses, Lisboa: Imprensa Nacional, 1997.

ZEDEÑO, Maria N.; BOWSER, Brenda J. The Archaeology of Meaningful Places. In: BOWSER, Brenda J.; ZEDEÑO, Maria N. (Ed.) The Archaeology of Meaningful Places. Salt Lake City: University of Utah Press, 2009. p.1-15.

ZUSE, Silvana. Variabilidade cerâmica e diversidade cultural no Alto rio Madeira, Rondônia. Tese (Doutorado em Arqueologia) - Museu de Arqueologia e Etnologia, Universidade de São Paulo (USP). São Paulo, 2014.

\section{NOTAS}

${ }^{1}$ Período geológico que compreende desde o fim da última glaciação, aproximadamente 10 mil anos AP, até hoje, marcado por um clima mais quente, com variações no volume de precipitações ao longo do tempo.

${ }^{2}$ Solos modificados antropicamente, marcadores arqueológicos para presença pretérita de populações indígenas. Associados ao manejo do solo e/ou estabelecimento de povos mais sedentários.

${ }^{3}$ Xingó não pode ser considerada uma cachoeira, trata-se de um local bem encaixado do rio São Francisco em que ocorrem corredeiras. A última cachoeira do São Francisco é a de Paulo Afonso. O sítio Justino encontra-se a meio caminho entre Xingó e a cachoeira de Paulo Afonso.

${ }^{4}$ Disponível em: http://www.cimi.org.br/site/pt-br/?system=news\&conteudo_id=6962\& action=read.

Artigo recebido em 17 de maio de 2017. Aprovado em 14 de julho de 2017. 